Прядко Олександр Михайлович, кандидат технічних наук, доцент, заслужений працівник культури України,

Київський національний університет культури імистецтв

\title{
ГЕНЕЗИС ТА СТАНОВЛЕННЯ ТЕХНОЛОГІЙ ЕКРАННОГО ЖИВОПИСУ
}

У статті з позииій мистецтввознавства та культурологї досліджується становлення технології живопису та ї̈ трансформація в сучасні екранні реалізації у форматі фототехнологій та кінотехнологій. Розглянуто визначення феномену технології екранного живопису.

Ключові слова: культура, живопис, художник, творчість, технологія, екран,кадр, фотографія, фотомистецฺтво, кіномистецчтво, цүифровий живопис.

В статье с позиций искусствоведения и культурологии исследуется становление технологии живописи и её трансформаџия в современные экранные реализации в виде фототехнологии и кинотехнологии. Рассмотрено определение феномена технологии экранной живописи.

Ключевые слова: культура, живопись, художник, творчество, технология, екран, кадр, фотография, фотоискусство, киноискусство, иүифровая живопись.

The article studies the becoming of painting technology and its transformation into a modern implementation of the screen in the form of photo and cinema technologies from the standpoint of art history and cultural. The definition of the phenomenon of screen technology painting is discussed.

Key words: culture, art, artist, creative, technology, screen, frame, photo, photo art, cinema, digital painting.

Еволюцію образотворчих мистецтв у їх різновидах із різних позицій науковці відстежували в рамках таких гуманітарних дисциплін, як мистецтвознавство, культурологія, філософія, психологія, соціологія, історія і теорія кіно та в окремих грунтовних дослідженнях. Становлення живопису, архітектури, театру, фотографії, кіно і телебачення та їх взаємозв' язок досліджується в роботах професора С. Безклубенка $[1,2,3]$. Режисер Ю. Іллєнко в книзі «Парадигма кіно» стверджує, що немає людини, яка знає в чому полягає кінофеномен і аналізує алгоритм створення кінофільму як художнього твору [4]. Художньо-образну своєрідність побудови фільму та його окремі технологічні аспекти розкрито в монографії В. Горпенка «Архітектоніка фільму» [5]. Соціально-культурні передумови появи кінематографічної технології та естетика візуальних образів розглянуто В. Скуратівським у монографії «Екранні мистецтва у соціокультурних процесах XX ст.: генеза, структура, функція» [6]. Часо-просторовим процесам моделювання екранної художньої реальності, їх еволюційному розвитку і 
специфіці отриманого «екранного продукту» присвячена робота І. Зубавіної [7]. Проведені цими авторами дослідження дають змогу розширити і переосмислити уявлення про еволюційні процеси в сучасних екранних мистецтвах. Проте залишається ще чимало «білих плям», зокрема недостатньо глибоко відстежені спорідненість екранного зображення з живописом, а також їх відмінність.

Ще понад десятиліття тому в монографії «Теорія культури» С. Безклубенко аргументовано стверджував: «кіно - це живопис» і якраз «...від живопису кіно успадкувало не тільки століттями виважені правила побудови картини (до речі: друга назва фільму) - щодо розміщення зображуваних фігур як на першому плані, так і в глибині простору (композиція кадру), і щодо поєднання кольорів (колорит), гри світла та тіні (рефлекси), виразності пластики тіла, системи пропориій та їх сприйняття, уявлень про повітряну перспективу і т.д. і т.п., але навіть саму форму обрамлення зображення» [8]. Проте далі справа не пішла. Поглиблено не досліджені не тільки «кровно-родинні» відносити кіно і живопису, але й те, що відрізняє одне від одного ці два різновиди живопису. А відмінність полягає в техніці та технології. Відмінності цього порядку, як відомо, відрізняють не тільки станковий живопис від монументального, акварельний - від темперного, темперний - від олійного, а й навіть особливості живописного стилю: імпресіонізм, експресіонізм, пуантилізм, постімпресіонізм... Тим не менш, особливості техніки та технології екранного живопису залишаються й досі мало вивченими. Цим і зумовлено вибір теми статті.

Мета статті - дослідити зародження та становлення екранного кіномистецтва як особливої технології екранного живопису.

До цього часу термін «екранний живопис» зазвичай незаслужено підмінявся терміном «екранне зображення», який не те, щоб був зовсім некоректним, - він відволікає увагу від суті. Акцентуація ж питань техніки та технології у відриві від посутньої мети їх винайдення та застосування - створення екранного живопису - й зовсім затьмарює справу: так, ніби йдеться не про образотворче мистецтво і його чи не найяскравіший різновид - живопис.

Тому досліджувати технології живопису і їх сучасні екранні різновиди видається необхідним розпочати здалеку, коли не з самого початку, передісторію їх зародження, виникнення і розвитку.

Усі різновиди живопису базуються на технічних засобах і технологіях, які тісно пов'язані між собою.

Технологія - це словосполучення двох грецьких слів: $\varepsilon \dot{z} \chi \eta-$ мистецтво, майстерність, вміння і це сукупність методів, процесів та матеріалів, які використовуються в тій чи іншій сфері діяльності, а також науковий опис їх застосування. Проглядається певною мірою тотожність слів технологія і мистецтво. Тому вибудовується такий логічний ланцюжок: «живопис»>〈«технологія»>《екран». При цьому використання терміну «технологія» обумовлене його широким функціональним застосуванням, бо термін «мистецтво» дещо звужує тему дослідження. Досить детально цю термінологію проаналізовано в роботі С. Безклубенка «Відеологія» [1].

В іншій роботі С. Безклубенка «Всезагальна теорія та історія мистецтва» [2] подано базові визначення живопису, які характеризують живопис як один із різновидів 
образотворчого мистецтва (тобто мистецтва, що створює зображення - образи людей, предметів, явищ природи та суспільного життя). А саме слово живопис-від словосполучення писати, тобто малювати та зображати щось живе, тобто, живо(життє)подібно. Технологія живопису на відміну, наприклад, від мозаїки реалізується на основі фарб і барвників.

У такий спосіб, «...живопис - це мистецтво, яке прагне за допомогою фарб створити на площині ілюзію тримірного простору і предметів, що перебувають у ньому. Власне, йдеться не про весь простір взагалі, а лише про цілком певну, виокремлену його частину. Тому неодмінним атрибутом живопису є рамка. Це не обов'язково рама дерев'яна, мідна, срібна або золота і т. д., але це завжди певна (умовна) межа самого зображення» $[1]$.

Досить умовно первинні різновиди живопису можна класифікувати в залежності від матеріалу основи та їі розмірів на: монументальний (на стінах, стелі і інших спорудах), станковий (з використанням мольберта), мініатюрний (книжковий та ін.), театрально-декоративний (оформлення сцени, шляхом створення декорацій).

Технології живопису розрізняють за матеріалом, яким сполучають, барвники: енкаустика, темпера, олія, акварель, емаль, тощо; за цільовим призначенням: декоративний (пейзаж, натюрморт, арабески, гротеск тощо), декоративноужитковий (розписи ваз, тканин, фарбування стін, предметів домашнього вжитку) і власне мистецький (художній),метою якого є створення певного художнього образу [2]. Така класифікація є досить умовною, оскільки, наприклад, портрет, виконаний у будьякій мистецькій техніці, може «належати» до першого-ліпшого різновиду (станкового, мініатюрного або стінового живопису) і при цьому бути мистецьким шедевром, але виконувати певну декоративну функцію. Живопис як мистецтво за приналежністю належить до певного творчого напряму (художньої течії, школи), або стилю (реалізм 3 його різновидами: критичний, поетичний, гіпер- , сюр-, та соц- і т.д. і т.п.; натуралізм, романтизм, імпресіонізм, експресіонізм, модерн, модернізм (або авангард) з його різновидами: кубізм, супрематизм, попарт, кіч, абстракціонізм (нефігуративний живопис), постмодернізм з його різновидами: (концептуалізм, соцарт, тощо).

Найбільшого прогресу та технологічних трансформацій досягнули станковий та мініатюрний живопис. В історії станкового живопису кожна велика мистецька епохачи то романське мистецтво чи готика, «ренесанс» чи бароко, класицизм чи романтизм відзначена чіткими, принципово відмінними один від одного технологічними прийомами створення творів живопису. Ідеї, заради втілення яких майстер береться за пензель при створенні картини, реалізуються щоразу в певному матеріалі і специфічними для цього технічними засобами [9]. Відпрацьована до деталей система візантійського живопису гарантувалаїі майстрам досягнення бажаної мети, але не задовольняла живописців епохи Відродження; прийоми живопису ренесансу свого часу були відкинуті майстрами бароко, а принципи, покладені в основу живопису класицизму, виявилися неприйнятними в епоху романтизму. Важливо, однак, що всередині кожного великого стилю існували напрямки або локальні школи, що характеризуються типовими тільки для них технікотехнологічними особливостями, які дають загальне уявлення про характер мистецтва певної епохи та регіону. При цьому характерною особливістю живопису середньовіччя 
була тенденція до універсалізму технологічних прийомів в межах окремих регіонів, тоді як в епоху Відродження ця ж тенденція простежується в рамках більш вузьких, національних, а пізніше - тільки в рамках місцевих художніх шкіл. Показово, що кожен раз, коли певна група творів станкового живопису стає об'єктом технологічного дослідження, ці місцеві школи і їх еволюція виявляють себе з особливою очевидністю.

Починаючи 3 XVII ст. європейський станковий живопис став на шлях «технологічного індивідуалізму», що вилилося в типове явище останньої третини XIX ст. Саме тут проходить межа, за якою нормативність у дотриманні технологічних прийомів створення живописного твору остаточно втрачає значення.

Якщо технологічні особливості живопису основних стилістичних напрямків були очевидні й раніше (нехай у найзагальнішому вигляді і не завжди правильно інтерпретовані), то сьогодні можна провести більш конкретну наукову диференціацію цих особливостей, говорити про наявність певних закономірностей, властивих творам певних епох, національних та місцевих шкіл, окремих майстрів. Це належить як до методу роботи фарбами, тобто власне до техніки живопису, так і до всієї сукупності технологічного процесу створення живописної картини, починаючи з вибору матеріалів i ïx обробки. Сьогодні можна говорити про існування типових (або характерних) ознак основи, грунту, малюнка, шару фарб. Після їх ідентифікації стало можливим зробити висновки про час або місце створення твору живопису, про існування канонічних форм ведення і самого процесу живопису для певних художніх шкіл та епох. Ще недавно мистецтвознавчі науки мало цікавили технології живопису. Думка, що технології живопису нібито не мають прямого зв’язку з творчим процесом створення картини, досить міцно вкоренилася в мистецтвознавстві другої половини XIX - першої половини XX ст. І хоча в живописі, як і будь-якому іншому виді образотворчого мистецтва, творче мислення невідривне від матеріалу й технічного прийому, функція яких значно ширша, ніж зазвичай прийнято вважати, мистецтвознавча традиція протягом століть складалася несприятливо для вивчення технології живопису. Погляд істориків мистецтва на процес творення картини формувався ніби як погляд «ззовні». Власне технологічні процеси живопису цікавили їх менше, так само, як і зацікавленість художників до технологічного аспекту майстерності.

В останні десятиліття ситуація змінюється. Процес зближення гуманітарних і природничих наук, що став нині реальним фактом розвитку наукової думки, не оминув і традиційно гуманітарні мистецтвознавство та культурологію. Успіхи, досягнуті у вивченні традиційних технологій живопису, сьогодні дають змогу широкому колу фахівців - кінознавцям, культурологам, мистецтвознавцям, реставраторам та ін. вирішувати поставлені перед ними нові завдання в дослідженні екранних технологій, спираючись на технологічні дані про твори живопису.

Водночас сучасні технології нових видів живопису (фототехнологія, кінотехнологія, відеотехнологія та ін.) потребують окремого, додаткового, детального вивчення та дослідження.

Сьогодні ні в кого з нас не викликає сумнівів той факт, що художня фотографія, яка використовує свої технології, є образотворчим мистецтвом і відображає творче бачення фотографа як художника. Проте ще на зорі розвитку фотографії протягом 
декількох десятиліть гостро поставало питання про те, чи можна віднести фотографію до мистецтва чи це лише засіб фіксації і передачі інформації про навколишній світ.

Початком зародженням фототехнології можна вважати використання художниками камери обскура (лат. camera obscūra - темна кімната), у стінці якої був зроблений отвір невеличкого діаметру, а на протилежній до отвору білій стінці-екрані закріплювали основу картини, на якій отримували перевернуте кольорове світло-тіньове зображення. Художнику залишалося тільки зробити начерк за цим зображенням. Розміри цієї темної кімнати давали можливість розміститись у ній і самому художнику. Щоб не перекривати тілом чи рукою світловий потік, художники на його шляху почали встановлювати просвітний екран з тонкого паперу натягнутого на раму. Стало значно зручніше тими чи іншими технологічними методами зареєструвати на цьому папері отримане оптичне зображення. Одним із перших у кінці XV ст. використав камеру обскура для зарисовок з натури Леонардо да Вінчі, про що він детально написав у «Трактаті про живопис».

У 1685 р. Йоганнес Цан спроектував портативну камеру обскура, в конструкції якої було використане дзеркало, розташоване під кутом $45^{\circ}$ до оптичної осі отвору в стінці камери. Дзеркало давало змогу отримати проекцію зображення того чи іншого об'єкта на матовій або ж прозорій скляній горизонтальній поверхні, яка накривалася тонким напівпрозорим папером - калькою. 3 цього часу художники, використовуючи камеру обскура як зручний для роботи стіл, переносили отримане зображення на папір. Тобто художники почали використовувати камеру обскура для створення своїх творів (пейзажів, портретів, побутових сцен), що значно прискорило технологічний процес живопису. Пізніше на місце отвору в стінці камери Цан встановив найпростіший об' єктив в вигляді одиночної збираючої лінзи, що суттєво збільшило яскравість отриманого зображення і його різкість. Тобто художники фактично отримали сучасну конструкцію фотокамери. Залишилося зробити лише один технологічний крок-замінити звичайний папір світлочутливим матеріалом, на якому можна було б зареєструвати оптичне зображення. Це сталося значно пізніше, завдяки технологічним розробкам невтомних експериментаторів-фотографів і вчених Жозефа Нісефра Ньєпса, Луї-Жака-Манде Дагера, Вільяма Тальбота, Джона Гершеля та ін.

Статус фотографії як мистецтва в середині ХІХ ст. розкривається найбільш яскраво в тих зв'язках, які склалися між фотографією та живописом. Поява фотографічного процесу породило «ударну хвилю», яка поширилася в усьому світі мистецтва. Спочатку в ньому побачили небезпечного суперника. Безробіття стало загрожувати ілюстраторам і художникам-графіками. Загроза здавалася ще більшою, оскільки художній ідеал детального реалізму в той час був повновладним. Почасти 3 сумом, почасти з приємним збудженням знаменитий живописець історичної тематики, представник академізму Поль Деларош зауважив, що «відтепер живопис помер». До речі, він також зазначив, що фотографія відповідає «всім вимогам мистецтва» і містить у собі всі принципи, які ведуть до «досконалості» [10]. Деякі художники змінили свою професію і освоїли нову на той час фототехнологію. Такий розвиток подій зробив велику послугу фотографії, оскільки з'явилося багато фотографів-художників, які знали всі «таємниці» традиційного живопису. Вороже ставлення до фотографії виявив французький 
поет і критик Шарль Бодлер, який засуджував дезертирство художників і відзначав корупцію у світі мистецтва. Хоча знання, інформація і навіть натхнення значною мірою почали залежати від фотографії, але що вона чудова, ніхто не повинен визнавати цього, про це зазначав видатний французький художник Жан Огюст Домінік Енгр [11].

На першому еволюційному етапі, коли з'явилися перші фотографічні відбитки, ніхто не сприймав фотографію всерйоз. Вона вважалася лише пустощами й дитячою забавкою для обмеженого кола людей. У перші роки після виникнення в силу технічних обмежень фотографія не могла претендувати ні на документальність, ні на художню цінність, ні на свободу світлових рішень і творчого бачення фотографа. Довгі роки знадобилися фотографії на те, щоб відвоювати місце у світі образотворчого мистецтва.

У XIX ст. була поширена думка про те, що до мистецтва належить тільки рукотворний твір. Тому вважалося, що фотографічні відбитки, які отримували за допомогою різних фізико-хімічних методів, не могли претендувати на статус мистецтва. Навіть незважаючи на те, що вже перше покоління фотографів намагалося оживити композицію своїх знімків різними цікавими технологіями, прийомами і підходами, фотографія так і залишалася поза увагою мистецтвознавців, вважалася випадковою та дивною ремісничою підробкою. Фотографія розглядалася в той час критиками мистецтва тільки як механічна копія реальності, здатна бути лише подобою художнього живопису. Аж до 20-30-х років ХХ ст. в статтях і публікаціях всерйоз ставилось питання про те, чи є фотографія мистецтвом чи це лише прикладне, практичне ремесло, де головну роль відіграє техніка і технологія, а не сам фотограф.

У розвитку фотографії як мистецтва варто виокремити кілька періодів. Навіть на зорі розвитку фотографії вона мало чим відрізнялася від живопису. Тобто фотографи намагалися застосовувати добре знайомі їм художні прийоми у фотографії. Вони знімали головним чином монументальні, нерухомі об’єкти. Тому перші фотографічні відбитки відносилися до жанру портрета або пейзажу. Потім внаслідок виникнення газетної індустрії в XIX ст., фотографія зайняла нішу документального свідчення тих чи інших подій. Можна сказати, що тоді ще не було мови про художню цінність фотографії. Точну дату коли ж фотографія дійсно стала мистецтвом назвати неможливо. Але історики фотомистецтва відзначають для себе знакову подію, що сталася у 1856 р. Тоді швед Оскар Г. Рейландер зробив унікальний комбінований відбиток з тридцяти різних ретушованих негативів. У його фотографії під назвою «Дві дороги життя» немов відтворювалася древня сага про вступ двох молодих людей в життя. Один з головних героїв на фотографії звертається до різних чеснот, до милосердя, до релігії та ремесел, а інший, навпаки, захоплюється такими гріховними принадами життя, як азартні ігри, вино і аморальність. Цей алегоричний знімок миттєво отримав широку популярність. I після виставки в Манчестері фотографію Рейландера придбала для колекції принца Альберта сама королева Вікторія. Цю комбіновану фотографію можна віднести до одного $з$ перших самостійних творів, що відносяться до фотомистецтва. Творчий підхід Оскара Г. Рейландера спирався, звичайно, на класичну мистецтвознавчу освіту, отриману ним в Римській академії. Надалі з його ім'ям пов'язані і різноманітні експерименти 3 фотомонтажем, і з розробкою подвійної експозиції, і з приголомшливою багатоекспозиційною фотографією. 
Справу Рейландера продовжив талановитий художник і фотограф Генрі Піч Робінсон, який прославився завдяки своєму комбінованому знімку «Помираюча», зробленому з п'яти негативів. На цій художньої фотографії була відображена дівчинка в кріслі, яка помирала, над нею сумно стоять ії сестра і мати, а батько дивиться у відчинене вікно. Знімок «Помираюча» піддався критиці за спотворення правди, але знайшов широку популярність. Його тут же придбав англійський королівський двір, а наслідний принц навіть дав Робінсону постійне замовлення на один відбиток будь-якої подібної фотографії. Сам Робінсон став провідним представником пікторіальної фотографії в Англії і Європі (pictorial - англ. живописний). Цей напрямок фотомистецтва і сьогодні займає свою нішу у фотографії. Національна спілка фотохудожників України (НСФХУ) провела в 2015 р. «Перший відкритий національний фотоконкурс пікторіальної фотографії». Стилістика пікторіальної фотографії реалізується за рахунок спеціальних ефектів, прийомів, техніки і технологій. Пікторіальний фотоживопис відрізняється розмитістю силуетів, відсутність різких деталей - подібно до картин художників-імпресіоністів.

Фотографія тривалий час не могла вийти з «тіні» живопису. Утім розвитку фотографії як самостійного мистецтва на початку минулого століття багато в чому сприяли регулярні виставки, на яких поряд із красивими кадрами глядачі могли побачити і цікаві фотографії, що заслуговували звання «художнього твору». Однією з перших таких міжнародних виставок була галерея фотографії зі скромною назвою «291», яку відкрив Альфред Стігліц в 1905 році в Нью-Йорку на 5-й авеню. Це була справжня виставка сучасного мистецтва, на якій імена відомих художників стояли в одному ряду 3 іменами фотографів.

3 початком 20-30-х років XX ст. у фотомистецтві починається новий період, безпосередньо пов'язаний з масовим випуском газет і журналів. Фотографія змінює свій стиль, віддаючи перевагу документалістиці і репортажній зйомці. Документальність і художня реалізація поступово спліталися у фотографії в єдине ціле. 3'явилося нове покоління фотохудожників, які за допомогою репортажної і документальної зйомки щодня відтворювали історію своєї країни і всього світу. Фотографія стає носієм історичної правди, відбитком реальних подій. Недарма в ці роки особливу цінність представляли різні плакати, фотоальбоми та журнали. Саме в ці роки почали з'являтися співдружності і спілки фотохудожників, які прагнули перетворити фотографію в самодостатній вид мистецтва.

У 60-70-ті роки XX ст. розпочалася епоха фотореалізму і сміливих експериментів 3 різними фотографічними технологіями і художніми прийомами. 3'являються нові жанри фотографії, в яких ключовим моментом стає авторський задум і творче бачення фотографа.

Про технологічну спорідненість станкового живопису і фотоживопису говорить наявність в обох технологіях основи, грунту, шару барвників та захисного шару. Як основу фотохудожники сьогодні використовують папір, пластик, тканини, фарфор та інші матеріали. Основа фототворів початкового періоду екранного живопису - це прозорі матеріали: скло, пластик, лавсан. Що стосується шару барвників, то в сучасній фото- і кіно технології на плівкову основу для отримання чорно-білих негативів 
наноситься світлочутлива фотоемульсія в вигляді желатинової суспензії мікрокристалів галогенідів срібла 3 подальшим їх відновленням в процесі хіміко-фотографічної обробки в мікрокристали срібла, які в залежності від концентрації і розмірів утворюють зображення різної оптичної густини в експонованому полі кадру [12].

Світлочутливі емульсії для кольорових фото-кіноматеріалів не тільки різні по спектральній чутливості, але і містять фарбуючі компоненти. Вони в процесі проявки створюють в світлочутливих шарах ділянки різної оптичної густини з трьох барвників (жовтого, пурпурного і блакитного кольору), які лежать в основі субтрактивного синтезу різнокольорового зображення.

Наступним кроком у фототехнологіях стало використання не тільки негативних, а й позитивних і оборотних плівок, що перевело фотомистецтво ще й у ранг екранного живопису, бо для розглядання діапозитивів-слайдів необхідно було здійснювати проекцію на екран чи переглядати слайди на просвіт.

Наступний етап у фотомистецтві пов'язаний з переходом від аналогових плівкових технологій на цифрові. Цифровий формат зображення дав змогу фотографам відійти від простого дзеркального відображення навколишньої дійсності. 3 появою цифрових фотоапаратів, комп'ютерів і графічних редакторів фотограф отримав можливість для вдосконалення своїх знімків, отримав можливість донести творче бачення фотохудожника і навіть створити ірреальний світ безпосередньо залучивши до фототехнології переглядові екранні системи в вигляді каліброваних моніторів, дисплеїв та відеопроекції. Хоча фотографія в наші дні стала масовим явищем, для фотографії як мистецтва як і раніше важливі вибірковість і особливий погляд фотохудожника, його вміння за допомогою фототехнологій та фотографічних засобів створити справжній твір мистецтва.

Незважаючи на те, що за допомогою цифрового фотоапарата можна зробити сотні знімків за лічені хвилини, безумовно, не кожен кадр можна віднести в розряд художніх. Сучасний фотохудожник висловлює своє бачення світу або авторський задум допомогою ракурсу, вмілої гри світла і тіні, кольору, тонкого вибору моменту зйомки та інших прийомів. Тільки людина-творець здатна вкласти в зображення частинку свого внутрішнього світу, щоб знімок «обріс» новими емоціями і розкрив талант самого фотохудожника. Але технологічна складова - це також невід'ємна частина творчого процесу, яка дає можливість правильно визначити експозиційні параметри, задати контраст зображення, вибрати тип об’єктива та його фокусну відстань, вибрати освітлювальні прилади та правильно побудувати схему освітлення, підібрати світлофільтр і т.д. Тільки таке поєднання допомагає отримати бажаний твір фотомистецтва.

Кіномистецтво і живопис - близькі родичі, які «поріднились» через фотографію, цю технічну дочку живопису й історично рідну неньку кінематографа [3]. Перші кроки від фототехнології до кінотехнології зробили спочатку Вільям Генрі Фокс Тальбот (William Henry Fox Talbot) в 1852 р. (він застосував імпульсне освітлення і отримав послідовність із кількох фотокадрів), а потім, в 1878 р. - Едвард Майбрідж (Eadweard J. Muybridge) створив систему з 24 фотокамер, за допомогою яких вдалося отримати послідовність з 24 фотокадрів зображення коня для дослідження «Саллі Гарднер у 
галопі», яке замовив губернатор Каліфорнії Л. Стенфорд, іменем якого пізніше був названий університет [13]. Е. Майбрідж також створив перший кінопроектор «зоопраксіскоп» (zoopraxiscope), до складу якого входили: 24-х лопатевий дисковий обтюратор, освітлювач, об'єктив, а також диск з 24-ма фотографіями на скляній основі фаз руху конячки Саллі Гарднер. Зоопраксіскоп дозволив отримати перше темпоральне, тобто в динаміці, екранне кінозображення коня, що біжить. Це ще не був кіноживопис, але підвалини були вже закладені. У наш час застосовується подібна до технології Майбріджа - технологія одночасної зйомки кілька десятками фотокамер. Така зйомка імітує рух самої камери, фіксуючи стоп-кадри. Наприклад зйомка 48 фотокамерами, розташованими по колу, дозволяє отримати 2-секундне оглядове кінозображення 3 різних точок зору «замороженого» об' єкта, який ніби «завис» у повітрі.

Потім були винаходи Томаса Альви Едісона (кінетограф і кінетоскоп, ідею яких він запозичив у Мейбріджа) і братів Луї та Огюста Люмьєр та їх перший комерційний кінопоказ 28 грудня 1895 р. Їхні 50-секундні кіноетюди заклали основи жанрового розмаїття кінематографа: від хронікально-документального («Вихід робітників 3 фабрики Люм’єрів», «Прибуття потягу на вокзал Ла-Сьота», «Прибуття делегатів на фотоконгрес в Ліоні») до ігрового (у глядачів особливим успіхом користувалася комедії «Веселий скелет» та «Политий поливальник»).

Технології кінематографу, як і фототехнології, народжувалося не кольоровим, а чорно-білими - як графіка і які пройшли еволюційний шлях від чорно-білих негативних, позитивних та оборотних плівок до кольорових різної ширини. Фотоживопис і екранний кіноживопис пройшли еволюційний розвиток і сформувалися як нові різновиди образотворчого мистецтва.

Живопис і плівковий кінематограф, починаючи з перших кроків після виникнення останнього, демонстрували найбільш тісний синтез, основу якого становило відтворення часо-простору. Плівковий кінематограф успадкував від живопису всі правила побудови картин (кадриків) та їх послідовності (фільму в цілому). Їх «серединний» медіум фотографія - спочатку поступалася по признаку темпоральності, але сучасні технології ліквідували цю прогалину.

Якраз від живопису екранне зображення перейняло форму-формат співвідношення сторін екрану спочатку за пропорціями кадру «німого» кіно 3:4 (1:1,33 «золотого розтину»), академічного для звукового кіно 1:1,375, а потім вже відповідно до сучасних співвідношень сторін екрану: кашетований $(1: 1,66$ та $1: 1,85)$, широкоекранний $(1: 2,35)$, широкоформатний $(1: 2,2)$ та багато інших.

Сучасний плівковий кінематограф - це спадкоємець живопису, бо те що ми бачимо на екранах, не що інше, як ілюзія тримірного простору на площині, створена за допомогою гри кольорів, світла та тіні [3]. При цьому потрібно пам’ятати, що тінь на екранному зображенні - це всього лише більша чи менша оптична густина в позитиві кадру i, як наслідок - та чи інша яскравість на площині екрану, а кольори - це спектральне розділення світла барвниками позитиву.

У результаті подальшого стрімкого розвитку мультимедійних комп'ютерних технологій на початку 1990-х років зароджується ще один вид екранного живопису«цифровий живопис». Цифровий живопис сьогодні широко використовується при 
оформленні книг (обкладинки, ілюстрації), в рекламному бізнесі (дизайн плакатів, упаковок і т.д.), домінує в індустрії комп’ютерних ігор, в сучасних кінотехнологіях та вже досить популярний і в аматорській творчості. Для створення цифрового живопису будь-якої складності необхідно мати потужний комп'ютер, графічний планшет (англ. digitizer), кілька спеціалізованих комп'ютерних програм, необхідний рівень знань, відповідну освіту i, безумовно, талант. Комп’ютер з дисплеєм та дігітайзер в екранній технології цифрового живопису - це такий самий інструмент, як і пензлик із мольбертом у класичному образотворчому мистецтві.

Візуальне сприйняття, зорові образи завжди були, є і будуть основним джерелом пізнання людиною навколишнього світу. Еволюція живопису відображає не тільки еволюцію у сфері культурної практики, але і в соціальних, психологічних, естетичних, ідеологічних і навіть політичних процесах життя суспільства, але і еволюцію нових візуальних форм впливу на індивідуума, народжує нові форми екранних технологій. Сьогодні образотворчі мистецтва, особливо екранні технології все більше слідують за технічним прогресом, а екранний живопис отримав нові високотехнологічні продукти образотворчого мистецтва: цифровий живопис, цифрову фотографію, цифровий кінематограф, цифрове телебачення та відео, мультимедіа.

\section{Лimepamypa:}

1. Безклубенко С. Д. Відеологія. Основи теорії екранних мистеитв / С. Д. Безклубенко. Київ : Альтерпрес, 2004. - 328 с. 2. Безклубенко С. Д. Всезагальна теорія та історія мистецттва / С. Д. Безклубенко. - Київ, 2003. - 261 с. 3. Безклубенко С. Д. Вступ до культурології / С. Д. Безклубенко. - Київ : Альтерпрес, 2015. - 508 с. 4. Іллєнко Ю. Г. Парадигма кіно / Ю. Г. Іллєнко. -Киї: Абрис, 1999. - 416 с. 5. Горпенко В. Г. Архітектоніка фільму: в 5 m. / В. Г. Горпенко. - Київ : КДІТМ, 2000. 6. Скуратівський В.Л. Екранні мистецтва у соціокультурних прочесах XX ст.: генеза, структура, функиія: у 2 ч. / В. Л. Скуратівський. - Ч. І. - Київ : КМЦ «Поезія», 1997. - 224 с.; Ч.ІІ-Київ : Іван Федоров, 1997. - 240 с. 7. Зубавіна I. Б. Екранна культура: засоби моделювання художньої реальності (час і простір у кінематографі): монографія / I. Б. Зубавіна. - Київ : Інтертехнологія, 2006. - 272 с. 8. Безклубенко С. Д. Теорія культури / С. Д. Безклубенко. - Чернігів, 2001. 472 c. 9. Гренберг Ю. И. Технология станковой живописи. История и исследование: монография / Ю. И. Гренберг. - Москва : Изобр. Искусство, 1982. - 320 с. 10. Bann, S. Paul Delaroche: History Painted / Stephen Bann. - London : Reaktion Books, 1997. - 304 p. 11. Изергина А. Н. Энгр об искусстве / А. Н. Изергина. - Москва : Изд-во Академии художеств СССР, 1962. - 172 с. 12. Прядко О. М. Сенситометрія / О. М. Прядко. - Київ : Освіта Украӥни, 2012. - 248 с. 13. Прядко О. М. Спеціальні види зйомок. Книга 1 / О. М. Прядко. - Київ : Освіта Украӥни, 2015. - 380 с. 